SOCIAL SCIENCE RESEARCH

Lutz Engelhardt

Entrepreneurial Business Models in the German Software Industry: Companies, Venture Capital, and Stock Market

Based Growth Strategies on the 'Neuer Markt'

SP II $2004-04$

March 2004

ISSN Nr. $0722-6748$

Research Area

Markets and Political Economy

Research Unit

Institutions, States, Markets
Forschungsschwerpunkt

Markt und politische Ökonomie

Abteilung

Institutionen, Staaten, Märkte 
Zitierweise/Citation:

Lutz Engelhardt, Entrepreneurial Business Models in the German Software Industry: Companies, Venture Capital, and Stock Market Based Growth Strategies on the 'Neuer Markt', Discussion Paper SP II 2004 - 04,

Wissenschaftszentrum Berlin, 2004.

Wissenschaftszentrum Berlin für Sozialforschung gGmbH,

Reichpietschufer 50, 10785 Berlin, Germany, Tel. (030) 25491 - 0

Internet: www.wz-berlin.de 


\section{Abstract \\ Entrepreneurial Business Models in the German Software Industry: Companies, Venture Capital, and Stock Market Based Growth Strategies on the 'Neuer Markt'}

by Lutz Engelhardt ${ }^{*}$

Young, radically innovative, growth oriented, and publicly listed high-tech companies in Silicon Valley together with venture capital financiers gave birth to the concept of the 'Entrepreneurial Business Model' (EBM). This concept has become central to the debate about the innovative capacity of nations in information technology and its promotion became an important policy objective in Germany during the 1990s. This paper addresses the question of whether German software companies on the former 'Neuer Markt' of the Frankfurt stock exchange were able to successfully implement business models similar to that of the typical entrepreneurial company in the United States. The paper focuses on the performance of software companies and venture capital investments on the 'Neuer Markt'. A number of findings emerge from this effort. First, successful German software companies implement traditional business models. The most successful German software companies specialize in IT- and software services. Such firms do not specialize in standardized software products which require little service and customization. Second, German venture capital for the most part was not able to establish successful entrepreneurial companies on the Silicon Valley model. Nor were they able to create a successful German variant of venture capital involvement in more traditional companies.

Keywords: Venture Capital, Software, Stock Markets, Germany, Entrepreneurial Business Models

JEL Classification: L86, G30

\footnotetext{
* I would like to thank Pablo Beramendi, Tom Cusack, and Sigurt Vitols for their detailed comments. The usual disclaimer applies. Partial support of the European Commission Key Action "Improving the socio-economic knowledge base” through contract No. HPSE-CT-2002-00146 is acknowledged.
} 


\section{Zusammenfassung}

\section{Entrepreneurial Business Models in der deutschen Softwareindustrie: Unternehmen,}

Wagniskapital und Aktienmarkt gestützte Wachstumsmodelle am ,Neuen Markt’

Junge, radikal innovative, schnell wachsende und börsennotierte Hightech-Unternehmen aus dem Silicon Valley und ihre Risikokapitalgeber standen Pate für den Begriff des ,Entrepreneurial Business Model' (,Unternehmerisches Geschäftsmodell'/ Wachstumsunternehmen). In den Diskussionen um die Innovationskraft einer Volkswirtschaft nimmt dieses Konzept eine prominente Stellung ein und wurde so zu einem der Hauptziele deutscher Wirtschaftförderung in den 90er Jahren. In diesem Beitrag wird der Frage nachgegangen, ob deutsche Softwareunternehmen des ,Neuen Marktes’ der Frankfurter Börse in der Lage waren, Geschäftsmodelle ähnlich dem des typischen amerikanischen Wachstumsunternehmen zu etablieren. Zu diesem Zweck wird die wirtschaftliche Leistung von Softwareunternehmen und Wagniskapitalinvestments am ,Neuen Markt' analysiert. Es zeigt sich zum ersten, dass die erfolgreichsten deutschen Softwareunternehmen keine klassischen Wachstumsunternehmen im amerikanischen Sinne sind, sondern traditionell wirtschaften. Die stärksten deutschen Softwareunternehmen haben sich auf serviceintensive IT- oder Softwareservices spezialisiert. Unternehmen, die standardisierte Software mit geringem Service- oder Personalisierungsanteil anbieten schneiden vergleichsweise schlecht ab. Es stellt sich zweitens heraus, dass deutsche Wagniskapitalgeber in ihrer Mehrheit nicht dazu in der Lage waren, starke Wachstumsunternehmen an den Markt zu bringen oder eine erfolgreiche deutsche Variante des Wagniskapitalinvestments in traditionellere Unternehmen zu entwickeln. 


\section{Introduction}

In the course of the 90s, the public debate about German competitiveness became dominated by concerns about national innovative capacity. Around that time, the development of new technologies lowered investment costs far enough to enable relatively small, young companies to outpace incumbent companies in the development of innovative products. This was especially true in the case of biotechnology, microelectronics and software. While the origins of this development can be found in the United States in the late 70s - in the case of software even earlier - it took approximately 25 years for this phenomenon to be regarded as a central defining characteristic of the national system of innovation in the United States. Based on the example of successful high-tech start-ups in the Silicon Valley, the term 'Entrepreneurial Business Model' (EBM) was coined. ${ }^{1}$ It denotes the organization, production and financing strategies implemented by the typical young, radically innovative, fast growing, and publicly listed company that came to dominate the information technology sectors in the United States.

Entrepreneurial companies (i.e. companies implementing an EBM), their contribution to innovation and growth, and their main structural prerequisites - such as special stock market segments for fast-growing companies ('growth segments') and venture capital (VC) - are some of the focal points in the debate about long-term German competitiveness (Pfirrman, Wupperfeld et al. 1997). During the 60s and 70s the lag of Germany in information technology was attributed to unfavorable industrial and trade policies designed to protect a few national champions (Bresnahan and Malerba 1999). However, during the 80s and 90s a lack of risk-tolerant, collateral-free equity finance for many SMEs and start-ups was identified as a particularly large impediment to a developed information technology sector. The high reliance on risk-averse debt capital in Germany is presumed to block product innovation in both new and incumbent companies (Lienhard von Zofingen 1987). VC combined with growth segments on stock markets is widely regarded to be the only viable source of working capital for companies in risky but potentially lucrative high technology fields (Gompers and Lerner 1996; Vitols 2001). Consequently there were a number of attempts to encourage the formation of entrepreneurial companies in Germany by constructing a supportive financial and institutional infrastructure. These attempts include the creation of a state funded German

\footnotetext{
${ }^{1}$ Frequently used synonymous terms are 'Silicon Valley' company, high-tech startup, new technology based firm (NTBF) or entrepreneurial company.
} 
VC company WFG (German Corporation for Venture Capital) at the beginning of the 80s, and the establishment of a stock market segment 'Geregelter Freiverkehr' at the end of the 80s, which was designed for companies that could not meet the strict admission requirements of the main market in Frankfurt (Stedler 1987; Wrede 1987; Klemm 1988). These attempts were largely unsuccessful. Nevertheless, the government continued to try to support the building up of venture capital capacity in Germany. The federal program BJTU (Participation Program for Young Technology-Based Firms) and its successor program BTU (Participation Program for Technology-Based Firms) in particular have directed considerable funding into different German VC projects throughout the 90s (Kulicke and Wupperfeld 1996). In the late90s more VC was available to German companies than at any previous point in history.

However, it was not until the creation of the 'Neuer Markt' as a dedicated growth segment of the Frankfurt stock exchange in 1997 that a larger number of relatively young companies went public in Germany, thereby creating a viable exit channel for German VC to cash in on investments. The 'Neuer Markt' was another attempt to create a receptive stock market for VC and entrepreneurial companies (Plückelmann 2000). The 'Neuer Markt' initially was promising, with hundreds of IPOs and lively VC participation. In the late 1990s it was easier to acquire VC in Germany than in the USA (Mackewicz\&Partner 2000). But the investment frenzy that came to an abrupt end with the burst of the stock market bubble in mid-2000 was a disastrous experience for many private investors. A number of companies traded on this segment had poorly conceived business models which could not realize the high expectations they created. Even though the 'Neuer Markt' was discontinued in 2003, a large number of companies listed on the 'Neuer Markt' are still traded at the Frankfurt stock exchange on two new segments - the Prime and the General Standard. Many of those companies are either doing relatively well or are gradually recovering from the economic downturn three years ago. Germany’s most sensational experimentation with Anglo-Saxon style EBMs clearly left its mark - over 350 companies went public during the 6 years $(03.10 .97-06.05 .03)$ the 'Neuer Markt' existed.

This paper addresses the question of whether the creation of the 'Neuer Markt' and the investment activity of venture capital had a positive effect on the development of entrepreneurial companies in a German setting. This effect is measured in terms of company financial performance. The software sector was chosen because software is one of the sectors in which EBMs are most prevalent (Landau and Rosenberg 1986). Therefore, the paper 
reviews post-IPO ${ }^{2}$ growth in sales and productivity as well as the general performance of the software companies which went public on the 'Neuer Markt' between 1997 and 2001. In addition, the role of VC for the development of those companies is assessed. Thus, the paper contributes to the discussion of the potential for success of EBMs in a German context, and of $\mathrm{VC}$ as a necessary precondition for this success.

The paper proceeds in three steps. First, the theoretical benefits of growth segments and VC for the evolution of software companies are described and the part they play in the concept of EBMs is laid out. The importance of growth segments and VC for the German problem of innovation bottlenecks is discussed. Second, the paper describes the performance as well as the structural features of the software companies on the 'Neuer Markt'. Here the paper deals with the question of the extent to which these companies have implemented EBMs. Based on the empirical evidence, it is demonstrated that there are examples of entrepreneurial companies on the 'Neuer Markt', but that they are for the most part unsuccessful. Instead, the most successful companies on the 'Neuer Markt' implement traditional business models. Accordingly, the connection between VC participation and company performance is analyzed. The key question here is if VC in Germany was able to bring especially fast growing and technologically advanced companies to the 'Neuer Markt'. It is shown that the presence of VC had no significant positive influence on the performance of companies. For the most part it was neither able to promote the implementation of EBMs at the 'Neuer Markt' nor to succeed in defining a German version of VC strategy. Finally, this paper comes to the conclusion that the existence of a stock market with an active growth segment and the general availability of VC are not sufficient preconditions for the successful emulation of Silicon Valley in Germany. German VC, at least in the history of the software companies on the 'Neuer Markt', lacks specific investment strengths in comparison with the Anglo-Saxon archetype.

\footnotetext{
${ }^{2}$ An initial public offering (IPO) is a company’s first offer to sell stock to the public.
} 


\section{Entrepreneurial Business Models, Venture Capital, and Stock Markets}

\section{Entrepreneurial Business Models in the Software Sector}

There is no generally accepted definition of EBMs. However, the term usually denotes business models of new companies which are founded to market highly innovative products or services. EBMs are usually associated with American success in high technology sectors namely software, electronics, and biotechnology. The typical company following an EBM was founded by one or more entrepreneurs to develop a specific product in a market where extraordinarily rapid sales growth can be achieved. The company is usually incorporated with the participation of VC. The start-up company's goal is to grow fast enough to obtain a listing on a stock market before the financial resources provided by the VCs are exhausted. This kind of company's fixation on growth and new products makes them relatively risky investments. ${ }^{3}$ An alternative, traditional type of company grows much more slowly, is solely reliant on debt finance or internal revenues for company finance, and is a less risky investment overall. The primary goal of this kind of company is sustainable business development rather than fast growth.

Patterns of corporate governance differ considerably between the two groups. The entrepreneurial company is subjected to diligent control efforts of the investor community, first by the venture capitalists and after its IPO by market actors. The traditional company provides its creditors with collateral and stays relatively closed to the outside world. Usually, the influence of investors, who do not for example take part in active management, is less pronounced than in the case of an entrepreneurial company. While the first type of company is normally associated with the way business is done in high-tech sectors in Anglo-Saxon countries (in particular in Silicon Valley), the second is regarded as typical for the German Mittelstand company (Vitols 2001).

\footnotetext{
${ }^{3}$ The implementation of an EBM does not necessarily imply new corporate empires in the tradition of Apple, Microsoft or Oracle. However, entrepreneurial companies represent a mode of radical technological innovation that is widely regarded, in high technology sectors at least, as individually and collectively superior to the inhouse research and development activities of established companies. Within this mode of company development, existing companies innovate and grow via acquisitions. The paradigmatic example of 'innovation by acquisition' used to be the network hardware producer Cisco Systems in the late 90s. This paper ignores companies belonging to this group. Instead, it concentrates on the independent and publicly traded software companies which are listed on the Prime and General Standard of the Frankfurt Stock Exchange and went public at the 'Neuer Markt' during the four year period between 1997 and 2001. Public availability of data is the one of the main advantages of studying publicly listed companies as opposed to private companies.
} 
Due to structural peculiarities of the software business, EBMs are widely regarded as indispensable for the creation of a truly successful software company. First, because of two distinct features of software products - increasing returns and network effects - rapid growth and early domination of its market segment is regarded as especially important for the long term success of a software company. Second, the importance of rapid sales growth and the fact that a major share of investment is used for the creation of intellectual property that is generally not accepted as loan collateral (lines of code in the case of software) makes it difficult for entrepreneurial companies to get bank loans. Therefore it is a particularly important competitive advantage to be able to get external equity finance in the software sector. The next two sections concentrate on the impact of increasing returns and network effects on the one hand and the importance of equity finance on the other.

\section{Increasing Returns and Network Effects}

Due to the impact of network effects and increasing returns one would expect the successful entrepreneurial software company to have a specific type of strategic orientation, organizational form, and economic performance. In principle the company should sell a product as standardized as possible to avoid the classical pitfall of decreasing marginal returns. Once the up-front investment for product development is incurred, the business model "scales up" (i.e. increases sales) without much additional cost. This is a result of the negligible production cost of additional copies of the company's software. With every extra unit sold returns increase as well, and are theoretically unlimited (Arthur 1996). ${ }^{4}$

Moreover, software is a so-called network product whose value increases when it becomes more widespread and established. As a result of the greater expected degree of compatibility and interoperability with other users, a potential costumer is likely to choose the predominant product. This tendency is called the network effect (Shapiro and Varian 1999). Given the potential for increasing returns and the impact of network effects, an already successful software company can be expected to dominate its market segment because of an everincreasing advantage over its competitors in revenue and profits. That is why software companies must grow as quickly as possible in order to become the dominant player in their

\footnotetext{
${ }^{4}$ This does not imply that a product has to be marketable without any customization and further human interaction. If a software product with high implementation and customization complexity is distributed and implemented by a third party this will not negatively influence the cost structure of the software producer itself.
} 
field of activity. In a winner-takes-all industry, the entrepreneurial company is thought to be the one best way to sustained profit, employment, and shareholder value generation (Lewis 1999). According to the EBM concept the combination of VC and growth market segments is most able to provide entrepreneurial companies with the necessary financial resources.

Here it becomes clear that the term EBM refers not only to the companies themselves but also to a collection of supportive institutions and actors. Entrepreneurs, abundant VC, liquid growth segments on the national stock market, specialized investment banks, and a vibrant investor community are the main elements of the infrastructure facilitating and supporting entrepreneurial companies (Lee, Miller et al. 2000). The next section concentrates on the main institutional pillars of EBMs: stock markets and venture capital.

\section{Venture Capital and Stock Markets}

The term VC denotes equity capital that specializes in providing finance to companies which are unable to rely on internal revenue or traditional lower cost sources of capital such as bank loans. Since considerable amounts of basic R\&D are funded by larger corporations or governments, many of the entrepreneurs come from existing companies or universities where they acquired the competencies and developed the initial idea for a start-up company. The entrepreneurial personality prefers the risk and potential reward of a start-up to the greater certainties of a career in the corporate world or at a university. Frequently, all that these entrepreneurs lack is the capital and the management techniques needed to transform a technology start-up into a successfully growing company. VCs specialize in the provision of both financial resources and management assistance. Thus, the entrepreneur and his or her shortcomings are the first important link between the EBM and VC (Zider 1998).

The second important link between the two concepts is the technology start-up's need for working capital. The typical entrepreneurial company is founded to specifically develop a highly innovative product with a large potential market. Due to a lack of collateral or of a extended history of profitability, these new and, in many cases, loss-making companies are dependent on outside funding to finance the initial research and development expenses, the production, marketing, and distribution investments which are necessary to prepare the company for a floatation on the stock market. Most VC investments, in Germany and 
elsewhere, concentrate on so called expansion and bridge financing (Schertler 2000). ${ }^{5}$ Much of the growth of these companies - and much of the value for the shareholders - comes after listing on the stock market. The venture capitalist prepares a company to tap the finance that is provided by the investors on the stock market. Normally, the venture capitalist sells the shares of a portfolio company after a group of investment banks helped it go public (i.e. sell its shares to the general investing public). In the concept of the EBM, the task of VC is to screen the business models and management teams of start-ups for viability, competency, and growth potential. Ideal typical venture capitalists seek to increase the probability of picking the right companies through intensive industry specialization and networking (Schertler and Stolpe 2000).

Finally, a liquid and receptive stock market is the single most important requirement for the VC investment calculus described above. The most lucrative exit channel for VC investments is the IPO. Trade sales (i.e. sales to other companies) and management buybacks are generally regarded as far less profitable. VC needs an active and risk-tolerant stock market to maximize business profitability and provide its portfolio companies with the finance required. ${ }^{6}$ Investors in turn see VC-backed companies as having higher quality than other companies going public. This is because venture capitalists need to safeguard their reputation in order to secure investors to finance and investment banks to make deals with their portfolio companies in the future (Gompers and Lerner 1996). In this sense, not only is a liquid stock market for highgrowth business models essential for the existence of an active venture capital market, but also the other way around. It would be much more costly for investors to assess the prospects of companies attempting an IPO without VC as a guarantor for a certain minimum level of quality of the company.

VC and growth stock markets or market segments are considered to be the principal prerequisites of a 'Silicon Valley' type of industry evolution, particularly in the German discussion of high-tech startups (Seitz 1990; Audretsch 1995; Partner 1998; Knips 2000). The rationale behind this point of view is that German industry and research institutes were in fact innovative, but were often unable to successfully commercialize their innovations. According

\footnotetext{
${ }^{5}$ The seed and start-up stages are the stages in which VC investment would support the R\&D phase of a new product. Expansion financing in essence prepares a company for the stock market in terms of scaling up operations. Bridge financing is mainly a financial investment which increases a company's equity to a level adequate for the stock market, and to cover the expenses of the IPO.

${ }^{6}$ This so-called 'pull'-thesis about the cyclical nature of VC activity is not unchallenged (Becker and Hellmann 2002). Competing explanations include long-term social change and the emergence of a powerful transformational technology ('push'-thesis) (Fiedler and Hellmann 2001).
} 
to this view, the American example has shown that new companies which implement an EBM best commercialize radical innovations. Two very important and necessary preconditions of commercialization of new technologies through entrepreneurial companies are VC and a stock market which provides venture capitalists with an exit channel.

Entrepreneurial vs. Traditional Business Models

A typical example for an entrepreneurial company is Silicon Valley's BEA Systems. The company, which developed from a venture capital-backed start-up founded in 1995 to a publicly listed, one billion dollar company in 2002, was able to define a whole new market segment - enterprise application integration. Software license revenues of BEA Systems account for approximately 50 percent of total turnover. License revenues are typically charged for a relatively standardized product which is sold in several copies, and not for tailor-made software for one customer. Operations which rely on a product mix characterized by a high percentage of software license revenues are likely to be scaled up easily. BEA Systems realized a compound annual growth rate of 34 percent between 1998 and 2002 and had a turnover of $\$ 934$ million with a 12 percent return on sales in 2002. BEA System has gained considerable reputation for being the fastest growing software company ever, even outpacing Microsoft. The two aspects of BEA System's business which are most important here are technological novelty and scalability. As described above, a successful software company has to grow as quickly as possible to dominate its respective market segment. A standardized distribution strategy and a market which is not yet consolidated (i.e. an immature market) are two important preconditions for that strategy to work.

The prime example for a traditional company of German origin is Bechtle AG. The company was founded in 1982 (13 years earlier than BEA Systems) and achieved a compound average growth rate of 42 percent between 1998 and 2002. The company’s turnover was $€ 751$ million in 2002 with a 2.5 percent return on sales (the figures for BEA Systems are 34 percent compound average growth rate, \$934 million turnover and 12 percent return on sales). Characteristically for the German software sector, Bechtle AG is an IT-service company with a broad product portfolio and with only a very tiny fraction of its yearly turnover generated through the sale of reusable software developed in-house. 
Table 1 gives a stylized summary of the two types of business models as described above. Profitability, growth, age, financing patterns, and corporate governance are variables which are relatively easy to measure. ${ }^{7}$ Numeric indicators of innovativeness and product standardization are more difficult to develop. In this paper four analytical categories are therefore used to measure these characteristics of a company's product and marketing strategies.

Table 1: Stylized Business Models: Entrepreneurial vs. Traditional

\begin{tabular}{|l|l|l|}
\hline & Entrepreneurial (USA) & Traditional (Germany) \\
\hline Innovation & $\begin{array}{l}\text { Radical innovation, deviating from } \\
\text { existing competencies and } \\
\text { technologies. }\end{array}$ & $\begin{array}{l}\text { Incremental innovation, securing } \\
\text { employees' and customers' } \\
\text { investments. }\end{array}$ \\
\hline Standardization & $\begin{array}{l}\text { High. Operations and production are } \\
\text { easy to scale. }\end{array}$ & $\begin{array}{l}\text { Low. A high proportion of costs are } \\
\text { variable (labor, etc.). }\end{array}$ \\
\hline Profitability & $\begin{array}{l}\text { Loss making in the R\&D stage. } \\
\text { Highly profitable once consolidated. }\end{array}$ & $\begin{array}{l}\text { Moderate profitability throughout the } \\
\text { entire business history. }\end{array}$ \\
\hline Growth & Offensive growth orientation. & Defensive growth orientation. \\
\hline Age at IPO & Young & Mature \\
\hline Finance & $\begin{array}{l}\text { Risk-tolerant equity. Share issues and } \\
\text { bond markets. }\end{array}$ & $\begin{array}{l}\text { Risk-averse debt. Bank and government } \\
\text { loans. }\end{array}$ \\
\hline $\begin{array}{l}\text { Corporate } \\
\text { Governance }\end{array}$ & $\begin{array}{l}\text { Outsider dominated: Venture } \\
\text { capitalists, institutional investors. } \\
\text { Investment protection via reporting. }\end{array}$ & $\begin{array}{l}\text { Insider dominated. Senior management. } \\
\text { Investment protection via collateral. }\end{array}$ \\
\hline
\end{tabular}

When differentiating between general software and services, business software, specialized software, and Internet software, one obtains a rough separation and ranking of the companies according to the technological novelty of their products as well as the general degree of product standardization in descending order (see Table 2) ${ }^{8}$

\footnotetext{
${ }^{7}$ Profitability, growth, and age are measures easily calculated with the information provided by annual reports. Entrepreneurial financing patterns and corporate governance structures are indicated through the presence of early-stage VC as shareholder and board member as publicized in the IPO prospectus of a company.

${ }^{8}$ The difference in product standardization between the first two groups as a whole and the latter two groups as a whole is the most pronounced. The differences between group 1 and group 2 and between group 3 and group 4 are not as large.
} 
Table 2: Four Categories of Software Companies

\begin{tabular}{|l|l|}
\hline Group 1: General Software and Services & $\begin{array}{l}\text { Project software, implementation, IT- } \\
\text { services. }\end{array}$ \\
\hline Group 2: Business Software & $\begin{array}{l}\text { Enterprise resource planning software, } \\
\text { customer relationship software, human } \\
\text { resources management software, financial } \\
\text { software. }\end{array}$ \\
\hline Group 3: Specialized Software & $\begin{array}{l}\text { Document management system, computer } \\
\text { aided design and manufacturing, } \\
\text { middleware, network infrastructure software. }\end{array}$ \\
\hline Group 4: Internet Software & $\begin{array}{l}\text { E-commerce software, security software, } \\
\text { Internet infrastructure software, web services } \\
\text { and application integration software. }\end{array}$ \\
\hline
\end{tabular}

The following sections present an empirical investigation into the structure and performance of 'Neuer Markt' software companies and VC based on these concepts. 


\section{Business Models and Venture Capital Participation on the 'Neuer Markt'}

To recapitulate, the first issue this paper is concerned with is the implementation of EBMs in Germany and the economic development of those companies. The second question is the role VC played for the development of the companies which underwent an IPO on the 'Neuer Markt'. The main concern here is the degree to which German VC could realize its intended potential role. In this section the model developed in the theoretical part of the paper (see table 1) is used to screen the population of former 'Neuer Markt' software companies for the existence of entrepreneurial companies. In order to asses the success of an industry group and its characteristic business model the groups are compared with each other, rather than with an external benchmark such as BEA Systems or some theoretically chosen quantity. In particular the differences between industry group 1 , the most traditional group, and group 4 , the most entrepreneurial group, are of interest for this paper. Furthermore, the paper is concerned with the degree to which the groups correspond with the framework laid out in table 1 when compared with each other. Which group is growing fastest, which is more profitable, and which had VC as an investor most frequently? Thus the paper tries to measure the extent of the existence of and performance of entrepreneurial companies in the German context.

\section{Business Models of German Software Companies}

A total of 105 software companies and IT-service companies conducted an IPO on the 'Neuer Markt' between 1997 and 2002. To date, 79 of these 105 companies survived as independent entities on the succeeding segments of the 'Neuer Markt' at the Frankfurt stock exchange (see table 3). These remaining 79 companies are struggling with the severe crisis affecting most segments of the software sector. Only 24 of 79 were profitable in 2002. However, at the end of 2002, 69 of 79 companies had higher revenues than they did at the end of 1998. Given that these companies had been operating in a depressed market for almost two years at the end of fiscal year 2002, a mean yearly compound average growth rate of 24\% between 1998 and the end of 2002 is not a poor performance. ${ }^{9}$ The development of employment at these companies yields a similar picture. Despite heavy lay-offs in the wake of the bursting of the Internet

\footnotetext{
${ }^{9}$ This average excludes three outliers with compound annual average growth rates much larger than $100 \%$.
} 
bubble and the slump in demand for information technology between 1998 and 2002, net employment at 'Neuer Markt' software companies increased by 17,891 jobs. ${ }^{10}$

Table 3: Status of Software Companies on the 'Neuer Markt', December 2003

\begin{tabular}{|l|l|l|}
\hline Current status & Number & Percentage \\
\hline In Operation & 79 & $75 \%$ \\
\hline Declared bankrupt & 18 & $17 \%$ \\
\hline Acquired & 7 & $7 \%$ \\
\hline Liquidated & 1 & $1 \%$ \\
\hline Total & 105 & $100.0 \%$ \\
\hline
\end{tabular}

Source: Own calculations based on press reports.

However, none of the software companies from the 'Neuer Markt' were able to achieve success comparable to American software firms based on the EBM concept ${ }^{11}$. Compared to the well-known American examples (e.g. BEA Systems which was described above) the track records of many German companies are characterized by a different, more conservative pattern. In general, German companies are far behind in either size, in growth rates, or in profitability. By and large, the biggest and most successful companies offer a hybrid of semicustomized software development for established markets and third party implementation services. Twelve of the twenty largest former 'Neuer Markt' companies are such IT-service firms which comprise group 1 (see table 4).

\footnotetext{
${ }^{10}$ This figure excludes companies that have been acquired or which have filed for bankruptcy.

${ }^{11}$ Admittedly, not all American firms following the EBM model succeeded. Still, this model has served as the basis for many companies’ success.
} 


\begin{tabular}{|l|c|c|c|c|c|}
\hline & \multicolumn{5}{|c|}{ Quartiles (descending) } \\
\hline $\begin{array}{l}\text { Group 1: } \\
\text { General Software and Services }\end{array}$ & $60(12)$ & $55(11)$ & $5(1)$ & $4(1)$ & $31(25)$ \\
\hline $\begin{array}{l}\text { Group 2: } \\
\text { Business Software }\end{array}$ & $15(3)$ & $10(2)$ & $25(5)$ & $24(5)$ & $19(15)$ \\
\hline $\begin{array}{l}\text { Group 3: } \\
\text { Specialized Software }\end{array}$ & $15(3)$ & $20(4)$ & $35(7)$ & $24(5)$ & $23(19)$ \\
\hline $\begin{array}{l}\text { Group 4: } \\
\text { Internet Software }\end{array}$ & $10(2)$ & $15(3)$ & $35(7)$ & $48(10)$ & $27(22)$ \\
\hline $\begin{array}{l}\text { Total } \\
\text { * Relative frequency in percent of industry group members by quartiles of sales 2002. Absolute number in } \\
\text { brackets. }\end{array}$ & $100(20)$ & $100(20)$ & $100(20)$ & $100(21)$ & $100(81)$ \\
\hline
\end{tabular}

The proportion of sales generated by software licenses revenues, i.e. by standardized software products, is between 0 and 10 percent for group 1 companies. In this case a high percentage of company revenues are generated through staff intensive implementation and programming services. Economies of scale are not very important in these types of services. The closest German match for a company like BEA Systems (a company which would fit into group 4) in terms of size and economic success is the above described Bechtle AG, which is a paradigmatic member of industry group 1.

On average the companies of group 1 are the most successful in terms of size and profitability (see table 5). ${ }^{12}$ This group has the lowest bankruptcy rate (7\%) of all the groups between 1997 and now. The advanced age, the established product and service portfolios, the low degree of product standardization, and the low growth rate (as compared to group 4, see below) identifies companies in group 1 as traditional in the sense of the classification in table 1 . This conclusion is supported by the fact that early-stage and expansion VC played a minor role for the companies of group 1 (see table 9, page 19). For the remainder of this paper group 1 will serve as a benchmark to asses the relative performance and structural features of other industry groups.

\footnotetext{
${ }^{12}$ Table 6 provides the same measurements as Table 5 'normalizing' the data for the respective company's year of IPO. This gives an impression of the companies' economic development taking into account their different positions in the capital market cycle. Here, this rearrangement does not lead to major differences in the group characteristics.
} 
Table 5: Properties of Software Companies on the 'Neuer Markt' in 2002 (mean, median, and standard deviation)

\begin{tabular}{|c|c|c|c|c|c|}
\hline & & $\begin{array}{c}\text { General Software } \\
\text { and Service } \\
(\mathrm{n} \sim 25) *\end{array}$ & $\begin{array}{c}\text { Business } \\
\text { Software }(n \sim 15)\end{array}$ & $\begin{array}{c}\text { Specialized } \\
\text { Software }(n \sim 19)\end{array}$ & $\begin{array}{l}\text { Internet Software } \\
\qquad(\mathrm{n} \sim 22)\end{array}$ \\
\hline \multirow{3}{*}{ Sales (Mio. Euro) } & mean & 141.5 & 43.0 & 41.6 & 34.1 \\
\hline & median & 72.1 & 23.3 & 22.3 & 19.9 \\
\hline & sd & 157.0 & 44.9 & 40.6 & 50.7 \\
\hline \multirow{3}{*}{ Return on sales (\%) } & mean & -10.3 & -13.8 & -55.3 & -41.1 \\
\hline & median & -5.7 & -7.7 & -15.5 & -32.5 \\
\hline & sd & 19.4 & 22.9 & 121.9 & 97.6 \\
\hline \multirow{3}{*}{$\begin{array}{l}4 \text { year compound } \\
\text { annual growth rate } \\
\text { of sales }(\%)^{\circ}\end{array}$} & mean & 28 & 26 & 12 & 64 \\
\hline & median & 24 & 21 & 14 & 48 \\
\hline & sd & 25 & 16 & 17 & 70 \\
\hline \multirow{3}{*}{ Age at IPO (years) } & mean & 16.7 & 20.6 & 16.1 & 12.2 \\
\hline & median & 14.5 & 21.0 & 16.0 & 9.0 \\
\hline & sd & 10.5 & 7.0 & 6.5 & 8.0 \\
\hline
\end{tabular}

${ }^{\circ} 98$ to 02 average compound growth rate.

* The number of companies used for the calculations of different cells varies due to different availability of company information

Table 6: Properties of Software Companies on the 'Neuer Markt' Two Years after their IPO (mean, median, and standard deviation)

\begin{tabular}{|c|c|c|c|c|c|}
\hline & & $\begin{array}{c}\text { General Software } \\
\text { and Service } \\
(\mathrm{n} \sim 26) * \\
\end{array}$ & $\begin{array}{c}\text { Business } \\
\text { Software }(n \sim 18)\end{array}$ & $\begin{array}{c}\text { Specialized } \\
\text { Software }(n \sim 23)\end{array}$ & $\begin{array}{l}\text { Internet Software } \\
(\mathrm{n} \sim 24)\end{array}$ \\
\hline Sales (Mio. Euro) & $\begin{array}{c}\text { mean } \\
\text { median } \\
\text { sd }\end{array}$ & $\begin{array}{l}152.4 \\
107.7 \\
154.5\end{array}$ & $\begin{array}{l}44.4 \\
23.9 \\
42.9\end{array}$ & $\begin{array}{l}44.3 \\
25.5 \\
37.8\end{array}$ & $\begin{array}{c}39.45 \\
20.4 \\
48.1\end{array}$ \\
\hline Return on sales (\%) & $\begin{array}{c}\text { mean } \\
\text { median } \\
\text { sd }\end{array}$ & $\begin{array}{l}-12.2 \\
-0.6 \\
34.4 \\
\end{array}$ & $\begin{array}{l}-28.9 \\
-27.7 \\
38.9 \\
\end{array}$ & $\begin{array}{l}-53.7 \\
-18.1 \\
103.4 \\
\end{array}$ & $\begin{array}{l}-88.1 \\
-32.9 \\
123.9 \\
\end{array}$ \\
\hline $\begin{array}{l}3 \text { year compound } \\
\text { annual growth rate of } \\
\text { sales }(\%)^{\circ}\end{array}$ & $\begin{array}{c}\text { mean } \\
\text { median } \\
\text { sd }\end{array}$ & $\begin{array}{l}44 \\
36 \\
33 \\
\end{array}$ & $\begin{array}{l}31 \\
26 \\
29 \\
\end{array}$ & $\begin{array}{l}15 \\
16 \\
24 \\
\end{array}$ & $\begin{array}{l}74 \\
64 \\
76 \\
\end{array}$ \\
\hline $\begin{array}{l}3 \text { year compound } \\
\text { annual growth rate of } \\
\text { productivity (\%) }{ }^{\circ}\end{array}$ & $\begin{array}{l}\text { mean } \\
\text { median } \\
\text { sd }\end{array}$ & $\begin{array}{l}-65 \\
-73 \\
21\end{array}$ & $\begin{array}{l}-75 \\
-76 \\
12\end{array}$ & $\begin{array}{c}-79 \\
-80 \\
10\end{array}$ & $\begin{array}{c}-78 \\
-78 \\
11\end{array}$ \\
\hline
\end{tabular}

${ }^{\circ} 1$ year before IPO to 2 years after IPO average compound growth rate.

* The number of companies which was used for the calculations of different cells varies due to different availability of company information 
Group 2 to a large extent consists of the old guard of German middle-sized ERP ${ }^{13}$ - and financial software companies. Group 2 is the group with the second highest bankruptcy rate (22\%). In particular the fates of Bäurer AG and Brain International AG demonstrate how the proceeds of an IPO can negatively affect a company. Both companies implemented a business model which is typical for group 2. Extensive industry specialization, hence a well-defined market-niche, and an implementation-intensive product architecture result in operations which neither scale up nor can be transplanted easily. Unable to grow internally and equally unprepared to integrate new acquisitions, both companies broke down when the acquired companies started to make losses at the start of the software industry's crisis in 2000. Other companies (e.g. SoftM AG, Infor AG, and FJA AG) successfully managed to avoid such pitfalls. Many of them, though, are likely to be taken over by a larger player in the course of the consolidation of the enterprise resource planning software sector. None of these companies managed to grow large enough to represent a power in the ERP software segment. However, the 'Neuer Markt' was able to provide the companies of group 1 and group 2 with financial resources which many of them were able to exploit successfully. The average compound growth rates of sales within these two groups are relatively high. Many of these companies managed to increase their revenues in absolute terms and were able to modernize their product range to a considerable extent.

The group of specialized software vendors (group 3) consists of companies which produce a variety of software. Their business models on average are technologically less established than those in group 1 and group 2, but are not as 'cutting-edge' as those in group 4. The group is more or less a catch-all for the companies which do not clearly belong to one of the other groups. Nevertheless, group 3 companies have a relatively standardized product in common, which in most cases is only applicable to a relatively small market. With some exceptions these companies could not use the proceeds of their IPOs to broaden their product portfolio sufficiently. As a result, $31 \%$ of this group's companies had to declare bankruptcy, i.e. the highest bankruptcy rate of all groups. On average the group is the least profitable and the slowest growing of the four industry groups.

A fourth group consists of companies which specialized in the Internet, e-commerce, security or application integration market as defined in table 2 (group 4). Table 5 shows that this group was younger at the time of IPO and grew faster than the companies in the other three groups.

\footnotetext{
${ }^{13}$ Enterprise Resource Planning Software. The most famous ERP Company in Germany is SAP which never was listed on the 'Neue Markt'.
} 
In terms of revenues, however, it is still the smallest and least profitable group. Though, the bankruptcy rate of group 4 is still relatively low (at $15 \%$ it is the second lowest rate of all four groups) this rate can be expected to increase in the near future.

The fate of the former e-commerce star Intershop AG, founded in 1992, can be regarded as symptomatic of group 4. After impressive successes in its first two years on the stock market, the company reached a peak turnover of €123 million, up from €17 million in 1998 (the year of floatation). In 2002 turnover plunged to $€ 40$ million. The medium-term survival of the company is insecure.

According to the definition of an entrepreneurial company as laid out in table 1, one would expect to find entrepreneurial companies in group 4. E-commerce software, security software, Internet infrastructure software, web services and application integration software represented the latest technological developments in software in the mid to late 90s. In comparison with the other industry groups the average product standardization of group 4 companies is higher. The software produced by these companies represents general purpose technologies with a much larger potential market than the software produced by the other three groups. These two factors indicate a high standardization potential, which along with technological novelty is another important element of the EBM concept. Their low age and high growth performance in comparison with the other industry groups are in line with the notion of an entrepreneurial company. The more frequent presence of early-stage and expansion VC and the higher participation of venture capitalists on company boards is another point that could mark the emergence of EBMs on the 'Neuer Markt' (see table 9, page 19).

However, one would expect virtually every member of group 4 to be founded with the participation of VC if the concept of EBMs would have already been deeply rooted 1997 when the 'Neuer Markt' came into existence. The lack of profitability and the relatively low size of the group in terms of sales are further points which do not support the conclusion that group 4 membership is an indicator for the successful implementation of EBMs amongst the software companies on the 'Neuer Markt'.

Table 7 provides a comparison between group 1 and group 4 regarding the degree of correspondence between expected values based on the stylized business models of table 1 and actual empirical characteristics of the groups as provided in tables 5, 6, and 9. Again, it is important to note that this is based on a comparison of the two extreme groups with each other and not to an abstract model or an ideal typical American success story. 
Table 7: Correspondence of Expected and Actual Values for Generalist and Internet Software Companies (Groups 1 and 4)

\begin{tabular}{|l|l|l|}
\hline & $\begin{array}{l}\text { Group 1: } \\
\text { General software and services and } \\
\text { group correspondence with stylized } \\
\text { traditional business model }\end{array}$ & $\begin{array}{l}\text { Group 4: } \\
\text { Internet software and group } \\
\text { correspondence with stylized EBM }\end{array}$ \\
\hline Innovation & High & High \\
\hline Standardization & High & High \\
\hline Profitability & Low & Low \\
\hline Growth & High & High \\
\hline Age at IPO & High & High \\
\hline Finance & High & Medium \\
\hline $\begin{array}{l}\text { Corporate } \\
\text { Governance }\end{array}$ & High & Medium \\
\hline
\end{tabular}

The description of the sample above shows that some German software companies on the 'Neuer Markt' have product market specialization characteristic of EBMs (group 4). Tables 6 and 7, however, suggest that, on the whole, companies with traditional products do better than those with radically innovative products. With regard to performance, the only notable difference between group 4 and the other groups is a higher growth rate. This, however, could be attributed to the lower initial revenue level of these companies (i.e. lower starting point) or their younger age, rather than successful expansion in a new business segment. Besides, these higher growth rates have not led to any company examples of major corporate success, industry domination, or employment creation. The best performing groups are the generalists and the enterprise software companies, both of which have a very specialized, industryspecific, and service-intensive product portfolio. The less standardized a software product is, the more suited it appears to be for the business model of a German software company. This presumption is also supported by a negative correlation for the 'Neuer Markt' software companies between the standardization of the software product sold on the one hand and size and profitability on the other hand (see table 8). This is a counterintuitive finding given that the more standardized a software product is, the less costly it should be to scale up and the easier it should theoretically be for a company to grow. 
Table 8: Correlation Coefficients of Sales, Return on Sales, and Software License Revenues as Percentage of Sales $(n=45)$

\begin{tabular}{|l|c|c|c|}
\hline & Sales & Return on sales & Lic. rev. as \% sales \\
\hline Sales & 1 & -- & -- \\
\hline Return on sales & $\begin{array}{c}0.12 \\
(0.26)\end{array}$ & 1 & - \\
\hline License revenue as \% & $\begin{array}{c}-0.26 \\
(0.05)\end{array}$ & -0.29 \\
sales & $(0.07)$ & 1 \\
\hline
\end{tabular}

Figure in parenthesis is level of significance.

Return on sales $=($ EBT/sales $) 2001$.

License Information $=$ mean $(\operatorname{sum}(1998$ to 2000)).

To sum up, it cannot be clearly concluded that typical EBMs (as defined in the theoretical part of this paper) can be found amongst the software companies on the 'Neuer Markt'. A group of companies have been identified which display certain properties associated with the concept of EBMs (group 4 companies). These companies are by no means the dominant group in our sample in terms of number or performance, as one would expect in the case of a growth segment like the 'Neuer Markt'. None of the companies was able to achieve a dominant or standard setting position in its target market. Furthermore, many companies were identified which one would not expect to find on a growth segment due to the static character of their business model and their resulting inability to grow rapidly. Nevertheless, many of those companies seemed to be able to capitalize on the proceeds they collected during their IPOs. Whereas the 'Neuer Markt' thus leaves a mixed impression as far as the fate of its software companies is concerned, it certainly did not excel as a growth segment by attracting successful entrepreneurial high-tech companies in large numbers. Only some elements of EBMs can be observed to a limited extent, such as a comparably high percentage of earlystage and expansion VC participation or the product specialization of group 4 companies.

\section{Venture Capital and German Software Companies}

The second aim of this paper is to describe and analyze the role VC capital played for software companies on the 'Neuer Markt'. Did VC investment concentrate on the Internet software companies of group 4 (as the concept of EBMs would suggest), or did VC operating 
on the 'Neuer Markt' develop original strategies tailored to the companies it has to work with in the German context? On a descriptive level, the information provided in table 9 answers the first question in the negative. VC investment appears to be evenly distributed between the traditional and the high-tech groups. A chi-square test fails to reject the hypothesis that the distribution of VC presence is independent of industry membership. This picture does not change when one narrows down the stage of VC investment to just early stage and expansion investment. ${ }^{14}$ This does not lead to a noticeable concentration in any of the sectors. There is also no significant clustering when looking at board membership of the venture capitalist, which would be an indicator of substantial involvement. The percentage of shares owned by the venture capitalists at the time of IPO is also independently distributed.

Table 9: Cross-tabulation of Four Industry Groups on Different Indicators of Venture Capital Involvement

\begin{tabular}{|c|c|c|c|c|}
\hline & $\begin{array}{l}\text { General } \\
\text { Software } \\
\text { and } \\
\text { Services } \\
(\mathrm{N}=30)\end{array}$ & $\begin{array}{l}\text { Business } \\
\text { Software } \\
(\mathrm{N}=29)\end{array}$ & $\begin{array}{l}\text { Specialized } \\
\text { Software } \\
(\mathrm{N}=19)\end{array}$ & $\begin{array}{l}\text { Internet } \\
\text { Software } \\
(\mathrm{N}=27)\end{array}$ \\
\hline VC investment present $^{\circ}$ & $23 \%$ & $13 \%$ & $52 \%$ & $37 \%$ \\
\hline VC has a member on the company's board ${ }^{\circ}$ & $10 \%$ & $10 \%$ & $15 \%$ & $18 \%$ \\
\hline Early stage or expansion (no bridge) $^{\circ}$ & $6 \%$ & $3 \%$ & $21 \%$ & $22 \%$ \\
\hline Average \% of shares hold by VC (at IPO)* & $7.2 \%$ & $3.1 \%$ & $7.3 \%$ & $9.7 \%$ \\
\hline
\end{tabular}

${ }^{\circ}$ Pearson chi2 is not significant.

*Mann-Whitney rank sum test not significant for any group.

The second question concerning VC - whether a typical German variety of VC came into existence at the 'Neuer Markt' - will be addressed in the next section. Different factors potentially influencing the growth and performance of the companies are examined in a regression analysis. The influence of VC and membership in one of the four industry groups on company performance will be tested using alternative explanatory variables. Thus, a complementary and statistically more refined perspective on entrepreneurial companies and VC investment in Germany is developed.

\footnotetext{
${ }^{14}$ See footnote number 5 on page 7.
} 


\section{Venture Capital and/ or Industry Membership as Determinants of Performance}

In this section the determinants of company performance from an entrepreneurial perspective are analyzed in more detail through two regression models. Both models are estimated with an ordinary least square regression (OLS) using the natural logarithm of all continuous variables to correct for non-normal distribution. The dependent variables are compound average sales growth and compound average productivity growth for the period one year before to two years after the company's IPO. These variables describe two important dimensions of corporate performance on the one hand and two central elements of EBMs on the other. If EBMs were a successful strategy for German software companies, then companies with the most novel product market focus and the easiest to scale product strategy (i.e. the Internet software companies) should have the fastest sales and productivity growth. We would also expect VC to have a positive influence on both the sales and productivity growth of a company because of its ability to identify the most lucrative investments in the sense of promising growth candidates. The compound annual growth rates of sales and productivity reach from the first year before going public to the second year on the stock market. ${ }^{15}$ For the purposes of comparative analysis it seems reasonable to use a "time to IPO normalized" dataset, since the timing of going public has a significant influence of the operation of a company. Therefore, the time structure of the dataset is transformed to a metric based on time relative to the date of IPO rather than on the basis of the calendar year.

The estimated models in mathematical notation are:

$$
L C G S=\alpha+\beta V C+\sum \tau_{i} I G_{i}+\sum \delta_{i} V C * I G_{i}+\sum \omega_{i} T I P O_{i}+\gamma L S B I 1+\varphi L A G E+\varepsilon
$$

with the natural logarithm of the average compound growth rate of sales (LCGS) as dependent variable and

$$
L C G P=\alpha+\beta V C+\sum \tau_{i} I G_{i}+\sum \delta_{i} V C * I G_{i}+\sum \omega_{i} T I P O_{i}+\gamma L S B I 1+\varepsilon
$$

with the natural logarithm of the average compound growth rate of productivity (LCGP) as dependent variable. VC is a dummy denoting the presence of venture capital, IG is a dummy

\footnotetext{
${ }^{15}$ Here technical productivity is used: sales/ number of employees.
} 
denoting the membership in one of the four industry groups, VC*IG are the interaction terms of VC and IG, TIPO is a dummy with three groups showing whether the IPO took place in 1997-1998, 1999 or 2000-2001, LAGE is the natural logarithm of the age of a company at IPO, and LSBI1 is the natural logarithm of sales at the beginning of the period (one year before IPO) the compound growth rates have been calculated for.

To test whether both dimensions of EBMs are present - i.e. the presence of VC in the Internet software group as fastest growing group (sales) with the easiest to scale business models (productivity) - we include industry group membership (IG), the presence of VC (VC) and the related interaction terms as dummy variables (VC*IG). The reference group for the industry dummies is group 1 (general service and software companies) which was identified as the predominant and most successful industry group in Germany. Hence, all statements about industry groups and VC involvement have to be understood in relation to this benchmark. The only issue concerning the type of VC which is important for this paper is bridge financing as opposed to early-stage and expansion financing. ${ }^{16}$ Here the paper will concentrate on any type of VC financing (early, expansion or bridge financing) as one group in comparison to companies with no VC participation at all. It is true that early-stage and expansion venture capital involvement requires a much higher degree of industry specialization and an entirely different set of management competencies on the part of the VC firm. The VC complex as whole, however, can be understood as a gatekeeper to financial markets. Thus, this paper concentrates on the performance of VC in general and not of specific subgroups.

As far as the representation of EBMs and the strategies of $\mathrm{VC}$ are concerned the regression could generate six meaningful scenarios in both cases. Each would represent a different configuration of industry success and VC involvement in Germany.

1. A positive and significant interaction term between the Internet software group and the presence of VC could be interpreted as the presence of companies with successfully implemented EBMs that perform better than group 1 companies that received venture financing.

2. A positive and significant interaction term between any other industry groups and the presence of VC could be interpreted as a German variant of VC specialization in companies that are technologically less advanced than group 4 members but which

\footnotetext{
${ }^{16}$ See footnote number 5 on page 7.
} 
still successfully outperform VC investment in the traditional generalist companies of group 1.

3. A positive and significant VC involvement variable alone (i.e. without any of the interaction terms being significant) would indicate an ability of German VC to screen potential growth candidates successfully without adopting a specific industry focus.

4. A positive and significant result for only one of the industry groups would imply an advantage of one of the industry sectors over the generalist companies and no specific influence of VC.

5. The general absence of significant relationships between performance and industry group or VC variables would indicate weak VC and the absence of a best performing industry group in Germany.

6. A significant negative relationship between any industry group variable or the interaction term of industry group and VC would indicate a general better performance of the generalist company (group 1) or the higher capacity of German VC to promote the development of the generalist companies.

\section{Determinants of Sales Growth}

For the regression on sales growth three additional variables were included as controls: the age of the company when it underwent the IPO (LAGE), the size of the company expressed as the sales figure one year before the IPO (LSBI1) ${ }^{17}$, and the time proximity of a company's IPO to the bursting of the Internet bubble and the subsequent industry crisis through a dummy variable (TIPO). The dummy divides the sample into three groups: One group that floated in 1997 or 1998, one group that floated in 1999 and a final group that floated in 2000 or 2001. All continuous variables in the model are logarithmic to correct for non-normal distribution.

Table 10 presents the estimation results for the first equation. The coefficients of age and size behave exactly as described in much of the literature. The older and the bigger a company is, the slower it grows. Not surprisingly, another influential factor is the timing of the company's IPO. The closer the IPO is to the peak of the software industry crisis in the year 2000, the

\footnotetext{
${ }^{17}$ For more detailed information and references on age, size, and sector membership as predictors for sales growth and about size and sector membership as predictors for productivity growth see (Whittington 1980; Dunne and Hughes 1994; Geroski, Machin et al. 1997; Söderbom and Teal 2001).
} 
greater the negative influence on the growth performance is in comparison to the years 1997 and 1998.

Two of the industry variables as well as the variables measuring VC participation in general and VC participation in different industry groups do not have a significant influence on the compound annual growth rate of sales. Companies belonging to the Internet software group do not grow significantly faster than generalist companies with more traditional product portfolios. An exception is the third industry group (specialized software). The coefficient is negative and significant. This corresponds with the account given in the above analysis of the different industry groups’ structure.

To sum up, it can be said that fundamental traits of the companies, such as age and growth, and the industry business cycle help explain differences in growth performance. Industry group membership or VC involvement have no significant influence. The empirical results do not provide any support for the existence of successful entrepreneurial companies in the Germany software sector. The relevant industry group (Internet software) does not perform significantly better in terms of sales growth than more traditional ones. Likewise, there is no evidence that VC was able to support the implementation of EBMs in the context of the 'Neuer Markt', or that a German variant of VC successfully emerged. ${ }^{18}$

\footnotetext{
${ }^{18}$ The picture did not change when narrowing down the definition of VC in the regression model to early-stage and expansion financing.
} 
Table 10: Determinants of Compound Annual Sales Growth

\begin{tabular}{|c|c|}
\hline $\begin{array}{l}\text { Log of compound average } \\
\text { growth rate of sales } \\
\text { (1 year before IPO to } 2 \text { years after) }\end{array}$ & $\begin{array}{l}\text { coefficient } \\
\text { (se) }\end{array}$ \\
\hline VC yes/ no (dummy) & $\begin{array}{l}-0.17 \\
(0.16)\end{array}$ \\
\hline Industry group 2 (dummy) & $\begin{array}{l}-0.13 \\
(0.08)\end{array}$ \\
\hline Industry group 3 (dummy) & $\begin{array}{l}-0.27^{\star \star \star} \\
(0.09)\end{array}$ \\
\hline Industry group 4 (dummy) & $\begin{array}{l}-0.07 \\
(0.09)\end{array}$ \\
\hline Interaction group $2 \times \mathrm{VC}$ & $\begin{array}{c}0.14 \\
(0.19)\end{array}$ \\
\hline Interaction group $3 \mathrm{x}$ VC & $\begin{array}{c}0.21 \\
(0.20)\end{array}$ \\
\hline Interaction group $4 \mathrm{x}$ VC & $\begin{array}{c}0.13 \\
(0.17)\end{array}$ \\
\hline IPO in 1999 (dummy) & $\begin{array}{l}-0.25^{\star \star \star} \\
(0.09)\end{array}$ \\
\hline IPO in 2000 and 2001 (dummy) & $\begin{array}{l}-0.35^{\star \star \star} \\
(0.09)\end{array}$ \\
\hline Log of sales one year before IPO & $\begin{array}{l}-0.07^{\star \star} \\
(0.03)\end{array}$ \\
\hline Log of age & $\begin{array}{l}-0.13^{\star \star \star} \\
(0.05)\end{array}$ \\
\hline Constant & $\begin{array}{l}1.04^{\star \star \star} \\
(0.15)\end{array}$ \\
\hline Adjusted $\mathrm{R}^{2}$ & 0.48 \\
\hline $\mathrm{N}$ & 79 \\
\hline
\end{tabular}




\section{Determinants of Productivity Growth}

For the regression on productivity growth only the initial size of the company and the dummies for the years of the IPO are used as controls. ${ }^{19}$ A somewhat different and less clear picture emerges (see table 11). The OLS regression yields significant negative estimates for the three industry group dummies, implying that all three groups perform significantly worse than group 1 as far as productivity growth is concerned. This finding is consistent with the negative correlation between product standardization on the one hand and size and profitability on the other reported above (table 8). Furthermore, there is a positive and barely significant relation between the interaction term of VC and the third industry group. VC, VC in group 2 and group 4, as well as the timing of the IPO have no significant influence on productivity growth.

The regression results do not provide any strong evidence supportive of the position that VC makes a positive contribution to productivity growth in the German software industry. In addition, there is no sign that the more standardized and novel companies perform better than the traditional generalist companies of group 1 . This fact is especially striking in the case of productivity growth as the generalist companies have operations that should theoretically be the most expensive to scale. There is evidence that VC presence in group 3 companies positively influences the productivity development of companies in this group compared to companies of group 1. Still, this is the only instance in which the presence of VC has a positive effect and it would be difficult to draw the conclusion that there is a systematic positive influence of VC on growth performance in general.

In general the regression on productivity growth suggests a structural disadvantage of companies specializing in segments with standardized products. One of the main assumptions of the concept of EBMs, the superiority of easy-to-scale production and distribution strategies, seems not to hold in the case of the German software companies listed on the 'Neuer Markt'. The customization strategies of the generalist companies in group 1 allow those companies to grow as fast as the more specialized companies do (see regression 1) and seem to be better suited to adjust to an industry crisis than the more specialized and standardized strategies.

\footnotetext{
${ }^{19}$ Age is normally not used as predictor of company productivity (Söderbom and Teal 2001). Therefore it was not includes as control in the second regression.
} 
Table 11: Determinants of Productivity Growth

\begin{tabular}{|c|c|}
\hline $\begin{array}{l}\text { Log of compound average } \\
\text { growth rate of productivity } \\
\text { (1 year before IPO to } 2 \text { years after) }\end{array}$ & $\begin{array}{l}\text { coefficient } \\
\text { (se) }\end{array}$ \\
\hline VC yes/ no (dummy) & $\begin{array}{l}-0.17 \\
(0.19)\end{array}$ \\
\hline Industry group 2 (dummy) & $\begin{array}{l}-0.25^{\star *} \\
(0.10)\end{array}$ \\
\hline Industry group 3 (dummy) & $\begin{array}{l}-0.40^{\star \star \star} \\
(0.12)\end{array}$ \\
\hline Industry group 4 (dummy) & $\begin{array}{l}-0.23^{\star} \\
(0.12)\end{array}$ \\
\hline Interaction group $2 \times \mathrm{VC}$ & $\begin{array}{l}0.26 \\
(0.24)\end{array}$ \\
\hline Interaction group $3 \mathrm{x}$ VC & $\begin{array}{r}0.43^{*} \\
(0.25)\end{array}$ \\
\hline Interaction group $4 \mathrm{x}$ VC & $\begin{array}{c}0.13 \\
(0.21)\end{array}$ \\
\hline IPO in 1999 (dummy) & $\begin{array}{l}-0.05 \\
(0.13)\end{array}$ \\
\hline IPO in 2000 and 2001 (dummy) & $\begin{array}{l}-0.06 \\
(0.13)\end{array}$ \\
\hline Log of sales one year before IPO & $\begin{array}{l}0.04 \\
(0.04)\end{array}$ \\
\hline Constant & $\begin{array}{l}-1.03^{\star \star \star} \\
(0.19)\end{array}$ \\
\hline Adjusted $\mathrm{R}^{2}$ & 0.27 \\
\hline $\mathrm{N}$ & 75 \\
\hline $\begin{array}{l}\text { Significantly different from zero at the } \\
(\star \star \star)\end{array}$ & $\left({ }^{* *}\right)$ and $1 \mathrm{pe}$ \\
\hline
\end{tabular}




\section{Lessons from the 'Neuer Markt' for Entrepreneurial Business Models in Germany}

\section{The Companies}

It is obvious that only a few of the software companies floated on the 'Neuer Markt' had the potential to become paradigmatic 'blockbuster product' companies. A large proportion of the companies can be regarded as established niche market players with relatively focused competences and customer groups. For those companies, the 'Neuer Markt' was an additional source of funding that helped at a time when German banks started to cut back their traditional loan-making activities. For some however, the IPO proceeds turned out to be a double-edged sword. Those companies operating in clearly defined niche markets with specialized organizational structures designed for intensive customer relationships turned out to be incapable of utilizing the fresh money and meeting the strategic requirements associated with publicly raised equity. In particular the growth imperative of the 'Neuer Markt' posed an almost insurmountable challenge to the management of those companies, particularly on the verge of a severe industry crisis.

On the other hand, we have observed that many software companies developed favorably after their IPO on the 'Neuer Markt'. These companies do not represent EBMs in the ideal typical sense, but since they became listed on a stock market they clearly departed from the traditional business model as presented in table 1 . Nevertheless, the paper has shown that the least standardized business models perform best in Germany. They managed to complete and modernize their product and service portfolios. They were able to grow to an unprecedented level without overstretching their integrative abilities. Arguably, their success would not have been possible without the equity raised through their IPOs. But still, we note that many of them do not have a promising future since their business models either have reached their natural limits or they are likely to be taken over in the near future in the course of further industry consolidation. The prime examples for this group of companies are the previously mentioned Bechtle AG or the surviving part of the old guard of German enterprise resource planning software - SoftM AG, Infor AG, and FJA AG. 
Whereas the track records of software companies on the 'Neuer Markt' do not imply a special ability of VC to identify outstanding growth candidates or a outstanding viability of entrepreneurial companies, it does demonstrate that the 'Neuer Markt' was able to provide some companies with the necessary funds to grow faster than was previously possible. Starting from the software companies which had an IPO on the 'Neuer Markt', the question is whether the lack of relationship between VC investment and the business model adopted is a typical phenomenon which should be regarded as an invariant feature of the German context. Did German VC fail? Is the German economy structurally unsuitable for EBMs due to a lack of supportive infrastructure, which could be changed through policy measures, or due to conservative market structures, which would be more difficult to change? Was the fate of the 'Neuer Markt' just a story about unfortunate timing?

The structure of VC involvement in IPOs on the 'Neuer Markt' is unfortunately not well suited to fully answer these questions. The market for VC was ultimately just another segment of the German economy's financial system, although less regulated than stock markets or the market for credit. Hence, venture capitalists were an integrated part of strategic decision making on these markets. If private, and to a certain degree institutional investors shift their behavior from investing to day-trading, thereby turning the stock market into a variation of an unstable futures market (Willett and Alway 2000, p. 61-67), the investment behavior of private equity and VC is bound to change as well. This is exactly what happened in the case of the 'Neuer Markt'. Thus the characteristics of companies supported by VC, as well as the patterns of observable financing strategies at the 'Neuer Markt', cannot readily be attributed to the German corporate and VC landscape. The special situation of the 'Neuer Markt' and its unfortunate collapse through overly speculative investments also plays a role here. Against this backdrop it would be informative to conduct a comparison with VC behavior on a foreign growth market where the institutional environment is theoretically more supportive of EBMs than in Germany.

To conclude, it can be stated that neither VC nor the 'Neuer Markt' could facilitate the development of successful EBMs amongst German software companies. Early stage and expansion VC did not concentrate its investment on the 'cutting-edge' companies of the Internet software group. Additionally, these companies have not been able to outperform more traditional competitors. On the contrary, the two best performing groups comprise the 
oldest and most established software companies of German industry, which have business models incompatible with the notion of EBMs. For the most part, German VC apparently failed to develop a mode of operation that enabled it to identify above average growth candidates or more profitable companies.

One must be cautious about concluding that growth and innovation strategies relying on the elements of EBMs in a German context are impossible. There is still insufficient information and analysis on these questions. More research must be done to conclusively answer the question of whether a 'German version' of EBMs is possible and what it could look like. 


\section{Bibliography}

Arthur, B. W. (1996). "Increasing Returns and the New World of Business." Harvard Business Review(July-August): 101-109.

Audretsch, D. B. (1995). The Innovation, Unemployment and Competitiveness Challenge in Germany. Berlin.

Becker, R. and T. Hellmann (2002). The Genesis of Venture Capital - Lessons from the German Experience. Palo Alto, Stanford University.

Bresnahan, T. F. and F. Malerba (1999). Industrial Dynamics and the Evolution of Firm's and Nation's Competitive Capabilities in the World Computer Industry. Sources of Industrial Leadership. D. C. Mowery and R. R. Nelson. Cambridge: 79-132.

Dunne, P. and A. Hughes (1994). "Age, Size and Survival: UK Companies in the 80s'." The Journal of Industrial Economics 42: 115-140.

Fiedler, M.-O. and T. Hellmann (2001). "Against All Odss: The Late but Rapid Development of the German Venture Capital Industry." Journal of Private Equity 4(4): 31-45.

Geroski, P. A., S. J. Machin, et al. (1997). "Corporate Growth and Profitability." The Journal of Industrial Economics 45: 171-189.

Gompers, P. A. and J. Lerner (1996). "Grandstanding the Venture Capital Industry." Journal of Financial Economics 42: 133-156.

Klemm, A. H. (1988). Die Finanzierung und Betreuung von Innovationsvorhaben durch Venture Capital Gesellschaften. Möglichkeiten und Grenzen der Übertragung des amerikanischen Venture Capital Konzeptes auf die Bundesrepublik Deutschland. Frankfurt a. M.

Knips, S. (2000). Risikokapital und Neuer Markt. Die Aktie als Instrument der Riskiokapitalbeschaffung für junge Technologieunternehmen. Frankfurt am Main.

Kulicke, M. and U. Wupperfeld (1996). Beteiligungskapital für junge Technologieunternehmen. Ergebnisse eines Modellversuchs. Heidelberg.

Landau, R. and N. Rosenberg, Eds. (1986). The Positive Sum Strategy: Harnessing Technology for Economic Growth. Washington. D.C.

Lee, C.-M., W. F. Miller, et al., Eds. (2000). The Sillicon Valley Edge. A Habitat for Innovation and Entrepreneurship. Stanford.

Lewis, T. G. (1999). Microsoft Rising and other Tales from Silicon Valley. Los Alamitos.

Lienhard von Zofingen, P. (1987). Risikokapital-Finanzierung aus der Sicht der Banken. Grundlagen, Ausprägungen und Konzeptionsvorschlag. Bern. 
Mackewicz\&Partner (2000). Mythos, Visionen, Chancen: Venture Capital in den USA, Deutschland und Europa. München.

Partner, M. (1998). Venture Capital and Corporate Venture Capital: Financing alternatives for Innovative Start-ups and Young Technological Companies in Germany. München.

Pfirrman, O., U. Wupperfeld, et al. (1997). Venture Capital and New Technology Based Firms. Berlin.

Plückelmann, K. (2000). Der Neue Markt der Deutschen Börse AG. Frankfurt am Main.

Schertler, A. (2000). Venture Capital Contracts: A Survey of the Recent Literature. Kiel, Kieler Institut für Weltwirtschaft.

Schertler, A. and M. Stolpe (2000). Venture Mania in Europe: Its Causes and Consequences. Kiel, Kieler Institut für Weltwirtschaft.

Seitz, K. (1990). Die japanisch amerikanische Herausforderung. Deutschlands Hochtechnologie-Industrien kämpfen ums überleben. München.

Shapiro, C. and H. R. Varian (1999). Information rules. A strategic guide to the network economy. Boston, Massachusetts.

Söderbom, M. and F. Teal (2001). Firm Size and Productivity. Oxford.

Stedler, H. (1987). Venture Capital und geregelter Freiverkehr. Eine empirische Studie. Frankfurt am Main.

Vitols, S. (2001). "Frankfurt's Neuer Markt and the IPO Explosion: Is Germany on the Road to Silicon Valley?" Economy and Society 30(4): 553-564.

Whittington, R. (1980). "The Profitability and Size of United Kingdom Companies, 1960-74." The Journal of Industrial Economics 28: 335-352.

Willett, B. and T. Alway (2000). Lessons UnLearned: Wall Streets Cyclical Madness and the Door Out of the Asylum. Ottawa.

Wrede, T. (1987). Venture Capital. Das us-amerikanische Modell und seine Umsetzung in der Bundesrepublik Deutschland. Köln.

Zider, B. (1998). "How Venture Capital Works." Harvard Business Review (NovemberDezember): 131-139. 

Bücher des Forschungsschwerpunkts Markt und politische Ökonomie

Books of the Research Area Markets and Political Economy

Thomas Cusack

A National Challenge at the Local Level: Citizens, Elites and Institutions in Reunified Germany

2003, Ashgate

Sebastian Kessing

Essays on Employment Protection

2003, Freie Universität Berlin,

http://www.diss.fu-berlin.de/2003/202

Daniel Krähmer

On Learning and Information in Markets and

Organizations

2003, Shaker Verlag

\section{Bob Hancké}

Large Firms and Institutional Change. Industrial

Renewal and Economic Restructuring in France

2002, Oxford University Press

Andreas Stephan

Essays on the Contribution of Public Infrastructure to Private: Production and its Political

Economy

2002, dissertation.de

Peter A. Hall, David Soskice (Eds.)

Varieties of Capitalism

2001, Oxford University Press

Hans Mewis

Essays on Herd Behavior and Strategic

Delegation

2001, Shaker Verlag

Andreas Moerke

Organisationslernen über Netzwerke - Die

personellen Verflechtungen von

Führungsgremien japanischer

Aktiengesellschaften

2001, Deutscher Universitäts-Verlag

Silke Neubauer

Multimarket Contact and Organizational Design

2001, Deutscher Universitäts-Verlag

Lars-Hendrik Röller, Christian Wey (Eds.)

Die Soziale Marktwirtschaft in der neuen

Weltwirtschaft, WZB Jahrbuch 2001

2001, edition sigma

Michael Tröge

Competition in Credit Markets: A Theoretic

Analysis

2001, Deutscher Universitäts-Verlag

Torben Iversen, Jonas Pontusson, David Soskice

(Eds.)

Unions, Employers, and Central Banks

2000, Cambridge University Press
Tobias Miarka

Financial Intermediation and Deregulation:

A Critical Analysis of Japanese Bank-Firm-

Relationships

2000, Physica-Verlag

Rita Zobel

Beschäftigungsveränderungen und organisationales Lernen in japanischen Industriengesellschaften

2000, Humboldt-Universität zu Berlin

http://dochost.rz.hu-berlin.de/dissertationen/zobelrita-2000-06-19

Jos Jansen

Essays on Incentives in Regulation and

Innovation

2000, Tilburg University

Ralph Siebert

Innovation, Research Joint Ventures, and Multiproduct Competition

2000, Humboldt-Universität zu Berlin

http://dochost.rz.hu-berlin.de/dissertationen/siebertralph-2000-03-23/

Damien J. Neven, Lars-Hendrik Röller (Eds.)

The Political Economy of Industrial Policy in

Europe and the Member States

2000, edition sigma

Jianping Yang

Bankbeziehungen deutscher Unternehmen:

Investitionsverhalten und Risikoanalyse

2000, Deutscher Universitäts-Verlag

Christoph Schenk

Cooperation between Competitors -

Subcontracting and the Influence of Information,

Production and Capacity on Market Structure and

Competition

1999, Humboldt-Universität zu Berlin

http://dochost.rz.hu-berlin.de/dissertationen/schenk-

christoph-1999-11-16

Horst Albach, Ulrike Görtzen, Rita Zobel (Eds.)

Information Processing as a Competitive

Advantage of Japanese Firms

1999, edition sigma

Dieter Köster

Wettbewerb in Netzproduktmärkten

1999, Deutscher Universitäts-Verlag

Christian Wey

Marktorganisation durch Standardisierung: Ein

Beitrag zur Neuen Institutionenökonomik des Marktes

1999, edition sigma 

Fredrik Andersson

Kai A. Konrad

Lars-Hendrik Röller

Christian Wey

Talat Mahmood Klaus Schömann

Talat Mahmood Klaus Schömann

Jos Jansen

Jos Jansen

Günter Franke Harris Schlesinger Richard C. Stapleton

Tomaso Duso

Johan Lagerlöf

Paul Heidhues

Olivier Cadot Lars-Hendrik Röller Andreas Stephan

Justus Haucap

Christian Wey

Heidrun C. Hoppe Emre Ozdenoren

Rainer Nitsche

Daniel Krähmer

J. Peter Murmann

Kai A. Konrad

Robert Nuscheler

Fredrik Andersson Kai A. Konrad
Human Capital Investment and Globalization in Extortionary States

Merger Control in the New Economy

Die Determinanten der Mirgrationsentscheidung von IT-Hochschulabsolventen aus Pakistan Empirische Befunde zur Ausgestaltung der deutschen „Green Card“

The Determinants of the Migration Decision of ITgraduates from Pakistan: Empirical Evidence for the Design of a German "Green Card"

The Effects of Disclosure Regulation on Innovative Firms: Common Values

The Effects of Disclosure Regulation on Innovative Firms: Private Values

Multiplicative Background Risk

On the Politics of the Regulatory Reform:

Econometric Evidence from the OECD Countries

On the Desirability of an Efficiency Defense in

Merger Control

Contribution to Productivity or Pork Barrel? The Two Faces of Infrastructure Investment

Unionization Structures and Firms' Incentives for Productivity Enhancing Investments

Intermediation in Innovation

On the Effectiveness of Anti-Predation Rules

Entry and Experimentation in

Oligopolistic Markets for Experience Goods

The Coevolution of Industries and National Institutions: Theory and Evidence

Terrorism and the State

Physician Reimbursement, Time-Consistency and the Quality of Care

Taxation and Education Investment in the Tertiary Sector
FS IV $02-06$

FS IV $02-11$

FS IV $02-12$

FS IV $02-15$

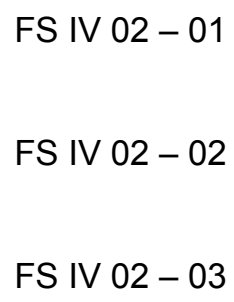

FS IV $02-02$ 
Jan Boone

Kai A. Konrad

Helmut Bester

Kai A. Konrad

Kjell Erik Lommerud Bjørn Sandvik

Odd Rune Straume

Steffen Huck Vicki Knoblauch Wieland Müller

Ralph Siebert

Jürgen Bracht

Saul Lach

Eyal Winter

Steffen Huck

Kai A. Konrad

Daniel Krähmer

Thomas Knaus

Robert Nuscheler

Kurt R. Brekke

Robert Nuscheler

Odd Rune Straume

Kai A. Konrad

Sebastian Kessing

Sebastian Kessing

Michal Grajek

Robert M. Adams Lars-Hendrik Röller

Robin C. Sickles

Tomaso Duso

Damien J. Neven Lars-Hendrik Röller

Tomaso Duso Astrid Jung
'Be nice, unless it pays to fight': A New Theory of

Price Determination with Implications for

Competition Policy

Altruism and Envy in Contests:

An Evolutionarily Stable Symbiosis

Delay in Contests

Good Jobs, Bad Jobs and Redistribution

On the Profitability of Collusion in Location Games

Learning by Doing and Multiproduction Effects over the Life Cycle: Evidence from the

Semiconductor Industry

Modeling Oligopolistic Price Adjustment in Micro

Level Panel Data

Strategic Trade Policy and the Home Bias in Firm

Ownership Structure

Delegation versus Authority

Incomplete Risk Adjustment and Adverse

Selection in the German Public Health Insurance System

Quality and Location Choices under Price

Regulation

Inverse Campaigning

A Note on the Determinants of Labour Share Movements

Employment Protection and Product Market Competition

Identification of Network Externalities in Markets for Non-Durables

Market Power in Outputs and Inputs: An Empirical Application to Banking

The Political Economy of European Merger Control: Evidence using Stock Market Data

Market Conduct and Endogenous Lobbying: Evidence from the U.S. Mobile Telecommunications Industry
FS IV $02-20$

FS IV $02-21$

FS IV $02-22$

FS IV $02-28$

FS IV $02-29$

FS IV $02-18$

FS IV $02-19$

FS IV $02-23$

FS IV $02-24$

FS IV $02-25$

FS IV $02-26$

FS IV $02-27$

FS IV $02-30$

FS IV $02-31$

FS IV $02-32$

FS IV $02-33$

FS IV $02-34$

FS IV $02-35$ 
Annette Boom

Kai A. Konrad Wolfram F. Richter

Stergios Skaperdas

Johan Lagerlöf

Roman Inderst

Christian Wey

Sebastian Kessing

Robert Nuscheler

Lars Frisell

Paul Heidhues Nicolas Melissas

Pablo Beramendi

Daniel Krähmer

Ralph Siebert

Vivek Ghosal

Vivek Ghosal

Andreas Blume

Paul Heidhues

Sebastian Kessing

Tomaso Duso Astrid Jung

Thomas R. Cusack Pablo Beramendi

Kjell Erik Lommerud Frode Meland Odd Rune Straume
Investments in Electricity Generating Capacity under Different Market Structures and with Endogenously Fixed Demand

Zur Berücksichtigung von Kindern bei umlagefinanzierter Alterssicherung

Restraining the Genuine Homo Economicus: Why the Economy cannot be divorced from its Governance

Insisting on a Non-Negative Price: Oligopoly, Uncertainty, Welfare, and Multiple Equilibria

Buyer Power and Supplier Incentives

SP II $2003-02$

SP || $2003-03$

SP || $2003-04$

SP II $2003-05$

Monopoly Pricing with Negative Network Effects:

The Case of Vaccines

The Breakdown of Authority

SP || $2003-07$

Equilibria in a Dynamic Global Game: The Role of Cohort Effects

Political Institutions and Income Inequality:

The Case of Decentralization

Learning and Self-Confidence in Contests

SP || $2003-10$

SP || $2003-11$ Incumbent Firms: Market Proliferation versus Cannibalization

Impact of Uncertainty and Sunk Costs on Firm Survival and Industry Dynamics

Endemic Volatility of Firms and Establishments:

Are Real Options Effects Important?

Private Monitoring in Auctions

SP || $2003-14$

Delay in Joint Projects

SP || $2003-15$

Product Market Competition and Lobbying

SP || $2003-16$

Coordination in the U.S. Mobile

Telecommunications Industry

Taxing Work: Some Political and Economic

SP || $2003-17$ Aspects of Labor Income Taxation

Globalisation and Union Opposition to Technological Change
SP || $2003-18$ 
Joseph Clougherty

Dan Anderberg Fredrik Andersson

Eugenio J. Miravete Lars-Hendrik Röller

Talat Mahmood Klaus Schömann

Talat Mahmood Klaus Schömann

Suchan Chae Paul Heidhues

Sigurt Vitols

Michal Grajek

Kai A. Konrad

Helmut Bester

Kai A. Konrad

Kai A. Konrad

Kai A. Konrad

Steffen Huck Kai A. Konrad
Industry Trade-Balance and Domestic Merger

Policy: Some Empirical Evidence from the U.S.

Stratification, Social Networks in the Labour Market, and Intergenerational Mobility

Estimating Markups under Nonlinear Pricing Competition

On the Migration Decision of IT-Graduates:

A Two-Level Nested Logit Model

Assessing the Migration Decision of Indian

IT-Graduates: An Empirical Analysis

Buyers Alliances for Bargaining Power

Negotiated Shareholder Value: The German Version of an Anglo-American Practice

Estimating Network Effects and Compatibility in Mobile Telecommunications

Bidding in Hierarchies

Easy Targets and the Timing of Conflict

Opinion Leaders, Influence Activities and Leadership Rents

Mobilität in mehrstufigen Ausbildungsturnieren

Moral Cost, Commitment and Committee Size
SP || $2003-19$

SP II $2003-20$

SP || $2003-21$

SP || $2003-22$

SP || $2003-23$

SP || $2003-24$

SP I| $2003-25$

SP || $2003-26$

SP || $2003-27$

SP || $2003-28$

SP || $2003-29$

SP || $2003-30$

SP || $2003-31$ 


\begin{tabular}{|c|c|c|}
\hline Jos Jansen & Partial Information Sharing in Cournot Oligopoly & SP II $2004-01$ \\
\hline $\begin{array}{l}\text { Johan Lagerlöf } \\
\text { Lars Frisell }\end{array}$ & $\begin{array}{l}\text { Lobbying, Information Transmission, and Unequal } \\
\text { Representation }\end{array}$ & SP II $2004-02$ \\
\hline Sigurt Vitols & $\begin{array}{l}\text { Changes in Germany's Bank Based Financial } \\
\text { System: A Varieties of Capitalism Perspective }\end{array}$ & SP II $2004-03$ \\
\hline Lutz Engelhardt & $\begin{array}{l}\text { Entrepreneurial Business Models in the German } \\
\text { Software Industry: Companies, Venture Capital, } \\
\text { and Stock Market Based Growth Strategies o the } \\
\text { „Neuer Markt' }\end{array}$ & SP II $2004-04$ \\
\hline
\end{tabular}



Bei Ihren Bestellungen von WZB-Papers schicken

Sie bitte unbedingt einen an Sie adressierten Auf-

kleber mit sowie je paper eine Briefmarke im Wert

von 0,51 Euro oder einen "Coupon Reponse Inter-

national " (für Besteller aus dem Ausland)
Please send a self addressed label and postage stamps in the amount of 0.51 Euro or a "CouponReponse International" (if you are ordering from outside Germany) for each WZB-paper requested

Absender / Return Address:

Wissenschaftszentrum Berlin

für Sozialforschung

Presse- und informationsreferat

Reichpietschufer 50

D-10785 Berlin-Tiergarten

Hiermit bestelle ich folgende(s)

Discussion paper(s):

Please send me the following Discussion paper(s):

Bestell-Nr. / Order no.

Autor/in, Kurztitel /Author(s) / Title(s) in brief 